\title{
Risks management in the hospital environment: incidence and risk factors associated with falls and pressure injuries in a clinical unit
}

\author{
Gerenciamento de riscos em ambiente hospitalar: incidência e fatores de riscos associados à queda e \\ lesão por pressão em unidade clínica \\ Gestión del riesgo en ambientes hospitalarios: incidencia y factores de riesgo asociados a la caída y
lesión por presión en una unidad clínica
}

Rayane Oliveira Cedraz ${ }^{1}(1)$ Cristiane Helena Gallasch ${ }^{1}$ (D)

Eugenio Fuentes Pérez Júnior ${ }^{1}$ (1)

Helena Ferraz Gomes ${ }^{1}$ (1)

Ronilson Gonçalves Rocha ${ }^{1}$ (1)

Vivian Aline Mininel $^{2}(1)$

1. Universidade do Estado do Rio de Janeiro.

Rio de Janeiro, RJ, Brasil.

2. Universidade Federal de São Carlos.

São Carlos, SP, Brasil.
Corresponding author:

Cristiane Helena Gallasch.

E-mail: cristiane.gallasch@gmail.com

Submitted on $08 / 17 / 2017$

Accepted on $11 / 09 / 2017$.

DOI: 10.1590/2177-9465-EAN-2017-0252

\begin{abstract}
Objective: To evaluate the incidence and risk factors associated with falls and pressure injuries in a clinical unit. Methods: A quantitative, cross-sectional, descriptive-exploratory study was conducted at a university hospital in Rio de Janeiro using secondary data from patient records and information of registers of patients treated in 2015/2016. Data were analyzed using descriptive and inferential statistics. Results: Of the 157 treated patients, women, cardiovascular (43.9\%) and oncological diseases (35.0\%) predominated. The risk and incidences of falls and pressure injuries were higher in men. There were significant associations of gender with the risk of falling, the occurrence of falls and pressure injuries, and between the length of hospital stay and risk of falling. Conclusion: Risk management is essential to promote patient safety and improve quality of health care. Nurse staff plays a fundamental role in the process of guiding activities, updating the nursing team and evaluating interventions. The use of tools, such as protocols and indicators, allows the optimization of the work process and the achievement of these goals.
\end{abstract}

Keywords: Nursing; patient safety; risk management.

\section{Resumo}

Objetivo: Avaliar incidência e fatores de riscos associados à queda e à lesão por pressão em unidade clínica. Método: Estudo quantitativo, transversal, descritivo-exploratório, realizado em um hospital universitário do Rio de Janeiro, utilizando dados de prontuários e registros de informações dos pacientes em 2015/2016, analisados por estatística descritiva e inferencial. Resultados: Entre 157 registros, predominaram mulheres, doenças cardiocirculatórias (43,9\%) e oncológicas (35,0\%). Risco, incidência de queda e de lesão por pressão foram maiores em homens. Houve associação entre sexo e risco de queda, ocorrência de queda e abertura de lesão por pressão, além de tempo de internação com risco de queda. Conclusão: A gestão de riscos em unidades clínicas é essencial para promover a segurança e qualidade da assistência. O enfermeiro tem papel fundamental no norteamento das atividades, atualização da equipe e avaliação das intervenções. Ferramentas como protocolos e indicadores permitem otimizar o processo de trabalho e o alcance dessas metas.

Palavras-chave: Enfermagem; Segurança do paciente; Gestão de riscos.

\section{Resumen}

Objetivo: Evaluar la incidencia y los factores de riesgo asociados con la caída y lesión por presión en una unidad clínica. Método: Estudio cuantitativo, transversal, descriptivo-exploratorio, realizado en un hospital universitario de Rio de Janeiro, utilizando datos del registros e informaciones de pacientes de 2015/2016, analizados por estadística descriptiva e inferencial. Resultados: Entre 157 registros, predominaron mujeres, enfermedades cardiovasculares $(43,9 \%)$ y oncológicas (35,0\%). Riesgo, incidencia de caída y presión por lesión más comunes entre hombres. Hubo asociación entre sexo y riesgo de caídas, ocurrencia y apertura de lesiones por presión, y duración de la internación con riesgo de caídas. Conclusión: La gestión del riesgo es importante para promover seguridad al paciente y calidad en la atención. Enfermeros tienen papel fundamental en coordinar actividades, actualizar el equipo y evaluar intervenciones. Herramientas como protocolos e indicadores permiten optimización del proceso de trabajo y el logro de estos objetivos.

Palabras clave: Enfermería; Seguridad del paciente; Gestión de riesgos. 


\section{INTRODUCTION}

Increasing and recurrent concerns about the safety and quality of care provided to patients in hospital environments are recognized in the practice of healthcare and nursing and in research. We see the development of actions and protocols in institutions around the world, as well as an increase of scientific publications on the subject, reflecting national policies and international agreements to promote safe and risk-free care. ${ }^{1}$

The promotion of patient safety, through risk management measures and the incorporation of good practices based on scientific evidence, is essential for the effectiveness of safe nursing care, including the prevention of incidents and injuries due to failures in health care. Thus, it is necessary to adopt coherent techniques and tools suitable for the dynamics of each location. ${ }^{1-4}$

Falls and pressure injuries have been reported among the incidents related to complications resulting from the care provided by multidisciplinary teams. These complications have been discussed in Brazil since 2010 as being important for the achievement of patient safety objectives. ${ }^{5,6}$

Patient falls have multifactorial etiology; they are correlated to visual deficits and reduction of muscle strength with individuals at a high risk of falls requiring permanent monitoring, since the result can cause changes to the patient's quality of life and functionality; there is even a risk of death in the elderly. ${ }^{7,8}$ Pressure injuries are also of concern as they affect the quality of life of patients, complicate the clinical picture, are associated to the development of infections and increase the hospitalization time. ${ }^{9}$

Over the years, hospital care has required adaptations of the nursing team, mainly in respect to technological, social and economic transformations in the modern world that have contributed to an increase of the life expectancy and consequently the aging of the population. ${ }^{10}$ Clinical units are spaces that receive patients who are highly dependent on nursing and palliative care. ${ }^{11}$ To ensure the quality and safety of nursing care, it is essential to recognize the profile of the public that is being attended, as well as possible risk factors, to support the design and prioritization of nursing actions.

The literature reports the need to identify the difficulties and challenges faced during the management of nursing activities in specific units, as well as the impediments experienced by professionals, using the results as a way of suggesting changes in the development of activities and work processes. ${ }^{12}$

The management of activities should include the identification of risks related to care at the admission of the patient and during hospitalization. Risk management is essential for patient safety; this complex task incorporates different aspects inherent to the professional practice and relevant to the quality of health care offered. It should be noted that excessive workload and insufficient staffing have already been mentioned as risks to patient safety. ${ }^{1}$
In addition, the use of health indicators is a fundamental element to identify real and potential problems in institutions, and are linked to possible quality and safety goals that should be achieved by services. ${ }^{13}$

The following questions emerged after the risk of falls and pressure injuries started to be evaluated in a clinical hospital unit as an integral part of the clinical nursing activities of a State University of Rio de Janeiro: "how can information on the risk of falls and pressure injuries assist nursing risk management?" and "What is the association between reported data of hospitalized patients and the risk factors associated with falls and pressure injuries?"

This study therefore aims to evaluate the incidence and risk factors related to falls and pressure injuries in a clinical unit.

\section{METHOD}

This quantitative, cross-sectional, descriptive-exploratory and inferential study investigated secondary data obtained from care reports and medical records of patients admitted in a clinical unit of a university hospital in the state of Rio de Janeiro from August 2015 to February 2016.The unit has a capacity of 16 beds for patients older than 18 years (eight female and eight male) with different pathologies, in particular cardiovascular, gastrointestinal, hematological and oncological disorders.

This study assessed the documentation of 157 patients who were hospitalized during the period delimited for data collection.

Based on the care reports and patient records analyzed during the six months of data collection, data on the sociodemographic and clinical profiles of the patients attended were collected. For this purpose, a data extraction form was designed by the research team. The variables evaluated included the gender, age, reason for hospitalization, length of hospital stay, preexisting illnesses, risk of falling (Morse Fall Scale), ${ }^{14}$ occurrence of falls, risk of pressure injuries (Braden scale), ${ }^{15}$ occurrence of pressure injuries and the reason for leaving the unit (hospital discharge, death, transfer or unspecified exits).

The Morse Fall Scale and the Braden Scale are widely used in the clinical evaluation of risks related to patient safety at hospital admission. The Morse Fall Scale ${ }^{14}$ assesses several factors that may lead to the patient losing their steadiness and falling. The scale also suggests some preventive interventions such as monitoring high-risk situations, including the use of hypotensive medications, obstacles in the patient's way, disorientation and agitation, age, and need of support for walking, among others. Moreover, the scale includes measures to reduce injuries if falls occur, including keeping the patient close to the nursing station, maintaining bed rails elevated and paying attention to the height of the bed.

The Braden Scale ${ }^{15}$ is used to identify the risks of skin lesions caused by pressure; the nurse assesses the patient's mobility, humidity, sensory perception, nutrition, friction and shear with the risk being classified as none, low, high or very high. 
Data were tabulated using Microsoft Excel $2013^{\circledR}$ software and analyzed using the IBM SPSS Statistics software 20 using descriptive statistics - absolute and relative frequencies for categorical variables - reviewed by an independent statistician. The Pearson Chi-square test was used to investigate the association between variables. The Chi-Square test is a nonparametric test, which aims to find a scatter value for two qualitative variables, assessing whether differences between observed proportions of events are significant or not in relation to the proportion of these events. ${ }^{16} \mathrm{~A} 95 \%$ confidence interval was considered, with $p$-values $<0.05$ identifying significant associations between the studied variables.

This study was approved by the Research Ethics Committee of the institution (\# 1.320.047). The necessity of informed consent was waived as data collection used documented information with no direct contact with patients. The research is in accordance with Resolution 466/2012 of the National Health Council and the Declaration of Helsinki.

\section{RESULTS}

The documentary records of 157 patients were analyzed after completing data collection. It should be noted that the variable "pre-existing diseases" was not evaluated, since this information was unavailable in more than $20 \%$ of the analyzed documents and so there would be inconsistency in the data evaluated. The sociodemographic and clinical characteristics of the study population are shown in Table 1.

The results show that the sample was composed mostly of women and there was a predominance of cardiovascular (43.9\%) and oncological diseases (35.0\%).

Regarding hospitalization time, $67.5 \%$ of the patients remained hospitalized for more than 15 days, and of these, $37.6 \%$ for a period longer than 31 days. It was observed that the great majority of the patients were young adults $(82.2 \%)$. More than half $(54.8 \%)$ left the unit due to hospital discharge.

The results regarding the evaluation of the risk and occurrence of pressure injuries and falls investigated using the Braden and Morse Fall scales, respectively are shown in Table 2.

Data obtained using the Morse Fall scale showed that $76.3 \%$ of men and $43.2 \%$ of women were identified as having moderate and high risk of falls. Of the population that presented risk of falling, there was an incidence of $43.4 \%$ of falls, which were more common among men, occurring in $75.7 \%$ of the patients.

More than four-fifths of the population (85.4\%) were at risk of falling. However, when the incidence of falls were compared between men and women, it was found that only $7.8 \%$ of women suffered a fall compared to $75.7 \%$ of men. The findings allow us to state that, in this population, men presented higher risk and a higher incidence of falls when compared to women.
Table 1. Sociodemographic and clinical characteristics of patients hospitalized during the data collection period. $\mathrm{n}=157$. Rio de Janeiro, 2016.

\begin{tabular}{|c|c|c|}
\hline Variable & $\mathbf{n}$ & $\%$ \\
\hline \multicolumn{3}{|l|}{ Gender } \\
\hline Female & 81 & 51.6 \\
\hline Male & 76 & 48.4 \\
\hline \multicolumn{3}{|l|}{ Age } \\
\hline $18-25$ years & 8 & 5.1 \\
\hline $26-35$ years & 34 & 21.7 \\
\hline $36-45$ years & 31 & 19.7 \\
\hline $46-55$ years & 27 & 17.2 \\
\hline $56-65$ years & 29 & 18.5 \\
\hline$\geq 66$ years & 28 & 17.8 \\
\hline \multicolumn{3}{|l|}{ Underlying disease } \\
\hline Cardiovascular disease & 69 & 43.9 \\
\hline Oncological disease & 55 & 35.0 \\
\hline Rheumatologic disease & 11 & 7.0 \\
\hline Infectious disease & 11 & 7.0 \\
\hline Gastrointestinal disease & 4 & 2.5 \\
\hline Not classified & 7 & 4.5 \\
\hline \multicolumn{3}{|l|}{ Time of hospitalization } \\
\hline Up to 7 days & 11 & 7.0 \\
\hline 8-14 days & 40 & 25.5 \\
\hline 15-30 days & 47 & 29.9 \\
\hline$\geq 31$ days & 59 & 37.6 \\
\hline \multicolumn{3}{|l|}{ Reason of leaving the unit } \\
\hline Discharge & 86 & 54.8 \\
\hline Death & 33 & 21.0 \\
\hline Transference & 23 & 14.6 \\
\hline Not specified & 15 & 9.6 \\
\hline Total & 157 & 100 \\
\hline
\end{tabular}

The data obtained using the Braden Scale showed that men had a higher risk of developing pressure injuries; $69.7 \%$ of high to moderate risk compared to $61.7 \%$ in women.

When comparing the genders for the incidence of pressure injuries, we found that $54.5 \%$ of men and $11.3 \%$ of women were affected. These results show that, in this study population, although the risk of pressure injuries was similar for both genders, the incidence of injuries was significantly higher in the male population. 
Table 2. Risk and occurrence of pressure injuries and falls in a clinical hospital unit. $\mathrm{n}=157$. Rio de Janeiro, 2016.

\begin{tabular}{lcccc}
\hline \multirow{2}{*}{ Variable } & \multicolumn{2}{c}{ Men } & \multicolumn{2}{c}{ Women } \\
& $\mathbf{n}$ & $\%$ & $\mathbf{n}$ & $\%$ \\
\hline Risk of falling & & & & \\
\hline$\quad$ None & 6 & 7.9 & 17 & 21.0 \\
Low risk & 12 & 15.8 & 29 & 35.8 \\
Moderate risk & 20 & 26.3 & 8 & 9.9 \\
$\quad$ High risk & 38 & 50.0 & 27 & 33.3 \\
\hline Occurrence of falls & & & & \\
\hline Yes & 53 & 69.7 & 5 & 6.2 \\
$\quad$ No & 23 & 30.3 & 76 & 93.8 \\
\hline Risk of pressure injuries & & & & \\
\hline No risk & 10 & 13.2 & 10 & 12.3 \\
$\quad$ Low risk & 13 & 17.1 & 21 & 25.9 \\
$\quad$ Moderate risk & 28 & 36.8 & 18 & 22.2 \\
$\quad$ High risk & 25 & 32.9 & 32 & 39.5 \\
\hline Occurrence of pressure injuries & & & & \\
\hline Yes & 36 & 47.4 & 8 & 9.9 \\
$\quad$ No & 40 & 52.6 & 73 & 90.1 \\
\hline Total & 157 & \multicolumn{2}{c}{100} \\
\hline
\end{tabular}

The results of the statistical tests identified associations in respect to gender, hospitalization time, underlying disease, risk of falling, occurrence of falling, risk of pressure injuries and occurrence of pressure injuries (Table 3 ).

Chi-square test demonstrated associations between gender and risk of falls, gender and occurrence of falls, and gender and occurrence of pressure injuries.

In addition, there was an association between hospitalization time and the risk of falls, with a low risk of falls for hospitalizations of up to seven days and a high risk of falls for patients hospitalized for periods greater than eight days.

On analyzing the relationship between the risk of pressure injuries and their occurrence, there was an association, with a higher statistical ratio for 'no-risk' and 'low-risk' versus nonoccurrence, as well as for 'moderate' and 'high risk' and the occurrence of pressure injuries (Table 2) showing that the Braden scale is effective at identifying the risk.

An association between the risk of falls and their occurrence was found, with a higher statistical ratio for 'none' and 'low risk' versus non-occurrence, as well as for 'moderate' and 'high risk' (Table 2).

It should be stressed that the statistical test did not indicate any association between the underlying disease and the risk or occurrence of falls or pressure injuries ( $p$-value $>0.05$ ).
Table 3. Associations between analyzed variables. $\mathrm{n}=157$. Rio de Janeiro, 2016.

\begin{tabular}{lc}
\hline Association & $\boldsymbol{p}$-value* \\
\hline Gender x risk of falls & $<0.001$ \\
\hline Gender x occurrence of falls & $<0.001$ \\
Gender x occurrence of pressure injuries & $<0.001$ \\
Hospitalization time x risk of falls & $<0.001$ \\
Risk of pressure injuries x occurrence of & 0.005 \\
pressure injuries & $<0.001$ \\
\hline Risk of falls x occurrence of falls & \\
\hline * Chi-square test. & \\
DISCUSSION &
\end{tabular}

The population of this study has characteristics that converge with data from the Brazilian Institute of Geography and Statistics (IBGE), ${ }^{18}$ as the most prevalent diseases in the study group are similar to those of the Brazilian population in general, i.e. cardiovascular diseases (43.9\%) followed by cancer (35.0\%). Non-communicable chronic diseases are constant in hospital admissions in Brazil, with a reduction in the rates of pulmonary diseases and constant rates for neoplasias, cardiovascular diseases and diabetes mellitus; the latter three are the most common causes for hospitalization. ${ }^{19}$

The relationship between social inequalities and morbidity and mortality in the population served by the Brazilian National Health System have already been reported in the literature. It is essential to recognize that health-related behaviors are important in respect to the effect of social inequalities on the morbidity and mortality of the population. The nursing staff can and should plan and implement a care plan that aims to promote healthy behaviors during hospitalization and after hospital discharge, as well as evaluating the effectiveness of this care. ${ }^{20,21}$

Furthermore, the use of indicators of the prevalence of pressure injuries and the incidence of falls have been used to evaluate different hospital settings..$^{22}$ This reinforces the need to evaluate and monitor each setting using management tools to carry out interventions related to these aspects.

Men present a higher risk and occurrence of falls. Falls, defined as total or partial loss of balance, can cause injuries with serious consequences in the hospital environment. Several factors contribute to the occurrence of falls; these factors can be extrinsic, such as an unknown environment, obstacles in the way and, inappropriate floors and shoes, or intrinsic, such as the use of hypotensive drugs, dependence on support to get around, delirium and bladder urgency. The findings of this study differ from the results reported in previous studies on the elderly population, which demonstrated that older women suffer more falls. ${ }^{7,23-25}$ 
Although the Morse Fall Scale is effective in identifying the risk of falls, the continuance of this event demonstrates the need for new research and intervention studies that highlight failures in their prevention.

In relation to pressure injuries, the highest incidence was found in men. Pressure injuries are local lesions to the skin and/ or soft tissues, usually over a prominent bone or related to the use of a medical device or other artifact. The lesion may present as unbroken skin or as an open ulcer, and may be painful. It results from intense and/or prolonged pressure in combination with shear. Tolerance of soft tissue to pressure and shear can also be affected by the microclimate, nutrition, perfusion, and comorbidities. The risk factors for pressure injuries are multivariate, with the main ones being mobility, degree of tissue perfusion and presence of injury due to the initial pressure. Other factors such as skin moisture, age, hematological variables, nutrition and general health are also important but not reported as frequently as the first three. Body temperature and immunity are cited in few studies, as well as ethnicity and gender, but without a high degree of evidence in their association with the occurrence of the lesion. ${ }^{26,27}$

It is known that keeping the skin unbroken is one of the indicators used to assess the quality of nursing care as advocated by the American Nursing Association (ANA); this may be hindered by failures in the organization of nursing work. Permanent education, coupled with good infrastructure, working conditions, nursing management and health management are essential elements to guarantee the quality of care processes..$^{28}$

The Braden Scale was also effective in identifying the risk of pressure injuries; however, the continuance of this complication demonstrates that other factors should be explored to propose interventions to reduce the incidence. The data generated from records of the care provided to the patient should be analyzed periodically by the nurse in order to promote safe and quality care and to raise awareness of the team in relation to importance of their work.

In Brazil, the recommendation of the Ministry of Health in relation to patient safety based on the international publications of the Joint Commission International $(\mathrm{JCl})$ guides national targets to be reached and guides multiprofessional actions such as patient identification, efficient communication, drug safety, safe surgery, hand washing and, the reduction of pressure ulcers and falls. For each goal, there is a range of recommendations according to each specialty and the profile of the patient. ${ }^{29}$

The literature describes and the Ministry of Health recommends the observation of several points to improve safety of care, including the physical environment, an adequate number of staff for the profile of patients, functioning protocols, and good communications within the multiprofessional team and with the patient, among others, in order to minimize possible injuries within the hospital. ${ }^{30}$
This research shows the relevance of risk management in a hospital environment in order to promote the quality of services and patient safety. The following are described in the literature as barriers or limitations to the development of the safety strategy by the nursing team: clinical variability, lacking protocols, lacking leadership, scarce material resources, insufficient staff, unsatisfactory teamwork, the pressure of care and time, insufficient incentives and motivation, and the absence of reliable security indicators - communication and safety culture and poor safety training. ${ }^{31,32}$

The implementation and incorporation of a safety culture depends on the level of commitment of the management and of the professionals, as well as on cohesion between departments and units, thereby guaranteeing safe care of the professional and patient. ${ }^{29}$ Moreover, nursing managers should consider the characteristics of the patients and the staff, implementing educational strategies for evidence-based practices focusing on the quality of care provided. It is well-known that qualifications give the health professional more confidence to develop care activities. $^{32-35}$

The limitations of the study were the impossibility of analyzing data related to comorbidities and previous diseases, as well as the inconsistencies relating to the Fugulim degree of dependence classification scale due to the absence of this information in more than $20 \%$ of the records. Since these are considered essential elements for the planning of nursing care, the organization of nursing tasks and the decision-making processes related to hospitalized patients, it is essential to systematize and use data collected in the care practice. The health registry is considered strategic for clinical and managerial decision-making, to support research and professional training, and is currently considered a criterion to assess the quality of health care delivered. ${ }^{17}$

\section{CONCLUSION}

This study presented the incidence and risk factors associated with falls and pressure injuries in patients hospitalized in a clinical unit, characterized as a young population, with a predominance of cardiovascular, metabolic (as diabetes mellitus) and neoplastic diseases, with a long hospitalization and elevated risk for falls and pressure ulcers. It showed that the risk and incidence of falls and pressure injuries was higher in men than in women.

Statistical tests showed an association between gender and risk of falling, gender and occurrence of falls, gender and the occurrence of pressure injuries, and length of hospital stay and risk of falls - a hospitalization time longer than eight days was associated with a higher risk of falls.

The results demonstrate the relevance of hospital risk management in promoting patient safety and the quality of 
services. Hence, nurses play a fundamental role in the process of guiding the activities, updating the team and evaluating interventions, allowing a review of practices to improve the quality of care, such as adapting protocols and the creation of new instruments that help to optimize the work of nurses.

The results also point to the need for strategies to mitigate incidents in the hospital environment, with actions that promote the quality of patient care and safety.

This study shows important aspects on the profile of patients that have a direct impact on the nursing process and the care provided. Conducting periodic evaluations and systematizing nursing care are thus an essential task in maintaining the quality of care, as they enable the nurse to review practices, adapt protocols and create new instruments that optimize time and teamwork.

It should be stressed that, in addition to periodic evaluations, it is also important to recognize the context and process of work, since risk management is a dynamic complex activity that should provide a safe and quality environment for workers. This involves a collective and articulated work among the various social actors involved in healthcare, seeking a balance between the health needs of the population and the conditions of work offered at the institution.

\section{REFERENCES}

1. Oliveira RM, Leitão IMTA, Silva LMS, Figueiredo SV, Sampaio RL, Gondim MM. Strategies for promoting patient safety: from the identification of the risks to the evidence-based practices. Esc Anna Nery [Internet]. 2014 Jan/Mar; [cited 2018 Jan 25]; 18(1):1229. Available from: http://www.scielo.br/scielo.php?pid=S141481452014000100122\&script=sci_arttext\&tlng=en

2. Fassini P, Hahn GV. Risk management in hospital unit: conceptions for nursing staff. Rev Enferm UFSM [Internet]. 2012; [cited 2018 Jan 25]; 2(2):290-9. Available from: http://bases.bireme.br/cgi-bin/wxislind.exe/ iah/online/?|sisScript=iah/iah. $x$ is\&src=google\&base=BDENF\&lang=p \&nextAction=Ink\&exprSearch=24667\&indexSearch=ID

3. Felli VEA, Peduzzi M, Leonello VM. Trabalho gerencial em enfermagem. In: Kurcgant T, coord. Gerenciamento em enfermagem. Rio de Janeiro: Guanabara Koogan; 2014. p. 21-32.

4. Almeida ML, Segui MLH, Maftum MA, Labronici LM, Peres AM. Management tools used by nurses in decision-making within the hospital context. Texto Contexto Enferm [Internet]. 2011; [cited 2018 Jan 25]; 20(no.esp):131-7. Available from: http://www.scielo.br/scielo. php?script=sci_arttext\&pid=S0104-07072011000500017

5. Oliveira JLC, Silva SVD, Santos PRD, Matsuda LM, Tonini NS, Nicola AL. Patient safety: knowledge between multiprofessional residents. Einstein (São Paulo). [Internet]. 2017; [cited 2018 Jan 25]; 15(1):50-7. Available from: https://www.ncbi.nlm.nih.gov/pubmed/28444089

6. Conselho Regional de Enfermagem (SP). Rede Brasileira de Enfermagem e Segurança do Paciente. 10 passos para a segurança do paciente. São Paulo: COREN-SP; 2010.

7. Abreu C, Mendes A, Monteiro J, Santos FR. Falls in hospital settings: a longitudinal study. Rev Latino Am Enferm [Internet]. 2012 May/Jun; [cited 2017 Oct 1]; 20(3):597-603. Available from: http://www.scielo.br/scielo. php?script=sci arttext\&pid=S0104-11692012000300023\&lng=en http://dx.doi.org/10.1590/S0104-11692012000300023
8. Remor CP, Cruz CB, Urbanetto JS. Analysis of fall risk factors in adults within the first 48 hours of hospitalization. Rev Gaúcha Enferm [Internet]. 2014 Dec; [cited 2018 Jan 25]; 35(4):28-34. Available from: http://www.scielo.br/scielo.php?script=sci_arttext\&pi $d=S 1983-14472014000400028$

9. Mittag BF, Krause TCC, Roehrs H, Meier MJ, Danski MTR. Care of Skin Injuries: Nursing Actions. ESTIMA [Internet]. 2017; [cited 2018 Jan 25]; 15(1):19-25. Available from: https://www.revistaestima.com.br/index. php/estima/issue/download/58/pdf_2

10. Vargas MAO, Luz AMH. Práticas seguras do/no cuidado de enfermagem no contexto hospitalar: é preciso pensar sobre isso e aquilo. Enferm Foco [Internet]. 2010; [cited 2018 Jan 25]; 1(1):23-7. Available from: http://revista.portalcofen.gov.br/index.php/enfermagem/article/view/5

11. Moraes A, Barbosa HA, Campos T, Nicola AL. Caracterização de pacientes internados em clínica médica segundo o grau de dependência do cuidado de enfermagem. In: Anais do Congresso Internacional de Humanidades \& Humanização em Saúde. [Blucher Medical Proceedings]. São Paulo: Blucher; 2014. 365 p. [cited 2016 Jun 30]. Available from: http://www.proceedings.blucher.com.br/ article-details/caracterizao-de-pacientes-internados-em-clnica-mdicasegundo-o-grau-de-dependncia-do-cuidado-de-enfermagem-9777

12. Zambiazi BRB, Costa AM. Nursing management in the emergency unit: problems and challenges. Rev Adm Saúde [Internet]. 2015; [cited 2018 Jan 25]; 15(61):169-76. Available from: http://bases.bireme.br/cgi-bin/ wxislind.exe/iah/online/?IsisScript=iah/iah.xis\&src=google\&base=LIL ACS\&lang=p\&nextAction=Ink\&exprSearch $=745019$ \&indexSearch $=I D$

13. Tronchin DMR, Melleiro MM, Kurcgant P, Garcia AN, Garzin ACA Subsídios teóricos para a construção e implantação de indicadores de qualidade em saúde. Rev Gaúcha Enferm [Internet]. 2009; [cited 2018 Jan 25]; 30(3):542-6. Available from: http://seer.ufrgs.br/ RevistaGauchadeEnfermagem/article/view/10412

14. Costa-Dias MJM, Ferreira PL, Oliveira AS. Adaptação cultural e linguística e validação da Escala de Quedas de Morse. Rev Enferm Refer [Internet]. 2014; [cited 2018 Jan 25]; 4(2):7-17. Available from: http://www.index-f.com/referencia/2014/r42-007.php

15. Maia ACAR, Pellegrino DMS, Blanes L, Dini GM, Ferreira LM Portuguese translation and validation of the Braden $Q$ scale for predicting pressure ulcer risk in pediatric patients. Rev Paul Pediatr [Internet]. 2011 Sep; [cited 2018 Jan 25]; 29(3):405-14. Available from: http://www.scielo.br/scielo.php?script=sci_arttext\&pid=S010305822011000300016\&lng=en\&nrm=iso\&tlng=en

16. Pluye $P$, Hong QN. Combining the power of stories and the power of numbers: mixed methods research and mixed studies reviews. Annu Rev Public Health [Internet]. 2014; [cited 2018 Jan 25]; 35:29-45. Available from: https://www.ncbi.nlm.nih.gov/pubmed/24188053

17. Vasconcellos MM, Gribel EB, Moraes IHS. Health records evaluation of patient health charts in primary care, Rio de Janeiro, Brazil. Cad Saúde Pública [Internet]. 2008; [cited 2018 Jan 25]; 24(Sup1):S173-82. Available from: http://www.scielo.br/scielo. php?script=sci_arttext\&pid=S0102-311X2008001300021

18. Ministério do Planejamento (BR). Orçamento e Gestão. Instituto Brasileiro de Geografia e Estatística IBGE. Censo demográfico [Internet]. 2014. [cited 2016 Sep 10]. Available from: http://www.ibge. gov.br/home/estatistica/economia/perfilmunic/2014/

19. Santos MAS, Oliveira MM, Andrade SSCA, Nunes ML, Malta DC Moura L. Non-communicable chronic disease hospital morbidity trends in Brazil, 2002-2012. Epidemiol Serv Saúde [Internet]. 2015 Jul/Sep [cited 2018 Jan 25]; 24(3):389-98. Available from: http://www.scielo.br/ scielo.php?script=sci_arttext\&pid=S2237-96222015000300389

20. Barros MBA, Francisco PMSB, Zanchetta LM, César CLG Trends in social and demographic inequalities in the prevalence of chronic diseases in Brazil. PNAD: 2003-2008. Ciênc Saúde Coletiva [Internet]. 2011 Sep; [cited 2018 Jan 25]; 16(9):3755-68. Available from: http://www.scielo.br/scielo.php?script=sci_arttext\&p $\mathrm{d}=$ S1413-81232011001000012 
21. Rodrigues BG, Lima CA, Cardoso NR, Rocha PT, Silva CSO, Gonçalves RPF. Management of nursing assistance: case study in a medical clinic in a university hospital. Gestão Saúde [Internet]. 2014; [cited 2018 Jan 25]; 5(1):253-62. Available from: http://www.ingentaconnect.com/content/do aj/19824785/2014/00000005/00000001/art00018

22. Melleiro MM, Tronchin DMR, Baptista CMC, Braga AT, Paulino $A$, Kurcgant $P$. Pressure ulcers prevalence indicators and patient falls incidence in teaching hospitals in the city of São Paulo. Rev Esc Enferm USP [Internet]. 2015 Dec; [cited 2018 Jan 25]; 49(no. esp2):55-9. Available from: http://www.scielo.br/scielo.php?pid=S008062342015000800055\&script=sci_arttext\&tIng=en

23. Dykes PC, Carroll DL, Hurley A, Lipsitz S, Benoit A, Chang F, et al. Fall prevention in acute care hospitals: a randomized trial. JAMA [Internet] 2010 Nov; [cited 2018 Jan 25]; 304(17):1912-8. Available from: https:// www.ncbi.nlm.nih.gov/pubmed/21045097

24. Almeida ST, Soldera CLC, Carli GA, Gomes I, Resende TL. Analysis of extrinsic and intrinsic factors that predispose elderly individuals to fall. Rev Assoc Med Bras [Internet]. 2012 Jul/Aug; [cited 2018 Jan 25]; 58(4):427-33. Available from: http://www.scielo.br/scielo. php?script=sci_arttext\&pid=S0104-42302012000400012

25. Rodrigues CL, Fernandes A, Armond JE. Factors associated with falls among the elderly assisted in a hospital at the south region of the city of São Paulo. Rev Bras Ciênc Saúde [Internet]. 2013; [cited 2018 Jan 25]; 11(36):14-9. Available from: http://seer.uscs.edu.br/index.php/ revista_ciencias_saude/article/view/1768

26. Coleman S, Gorecki C, Nelson EA, Closs SJ, Defloor T, Halfens R, et al Patient risk factors for pressure ulcer development: Systematic review. Int J Nurs Stud [Internet]. 2013 Jul; [cited 2018 Jan 25]; 50(7):974-1003. Available from: https://www.ncbi.nlm.nih.gov/pubmed/23375662

27. Caliri MHL, Santos VLCG, Mandelbaum MHS. Publicação oficial da Associação Brasileira de Estomaterapia - SOBEST e da Associação Brasileira de Enfermagem em Dermatologia - SOBENDE. 2016. [cited 2016 Oct 1]. Available from: http://www.sobest.org.br/textod/35

28. Anselmi ML, Peduzzi M, França Junior I. Incidence of pressure ulcer and nursing interventions. Acta Paul Enferm [Internet]. 2009 May/Jun; [cited 2018 Jan 25]; 22(3):257-64. Available from: http://www.scielo.br/scielo. php?pid=S0103-21002009000300004\&script=sci_arttext\&tIng=en

29. Ministério da Saúde (BR). Programa Nacional de Segurança do Paciente (PNSP). Portaria № 529 de 1o de abril de 2013. Institui o Programa Nacional de Segurança do Paciente (PNSP). Brasília (DF): Ministério da
Saúde [Internet]; 2013. [cited 2017 Feb 22]. Available from: http://bvsms. saude.gov.br/bvs/saudelegis/gm/2013/prt0529_01_04_2013.html

30. Ministério da Saúde (BR). Agência Nacional de Vigilância Sanitária. Segurança do Paciente E Qualidade Dos Serviços De Saúde Implantação Do Núcleo De Segurança Do Paciente Em Serviços De Saúde. Brasília: Anvisa [Internet]; 2015. [cited 2018 Jan 25] Available from: http://portal.anvisa.gov.br/documents/33852/3507912/ Caderno+6+-+Implanta\%C3\%A7\%C3\%A3o+do+N\%C3\%BAcleo+de+ Seguran\%C3\%A7a+do+Paciente+em+Servi\%C3\%A7os+de+Sa\%C3 \%BAde/cb237a40-ffd1-401f-b7fd-7371e495755c

31. Lima RS, Lourenço EB, Rosado SR, Sanches RS, Fava SMCL, Dázio EMR. Managing hospital ward: what nurses think? Rev Enferm Cent Oeste Min [Internet]. 2016; [cited 2018 Jan 25]; 6(2):2190-8. Available from: http://www.seer.ufsj.edu.br/index.php/recom/article/view/1128

32. Ques AAM, Montoro CH, González MG. Strengths and Threats Regarding the Patient's Safety: Nursing Professionals' Opinion. Rev Latino Am Enferm [Internet]. 2010 May/Jun; [cited 2017 Mar 2] 18(3):339-45. Available from: http://www.scielo.br/scielo. php?script=sci_arttext\&pid=S0104-11692010000300007\&lng=en

33. Oliveira OJ. Gestão da Qualidade: tópicos avançados. São Paulo: Cengage Learning; 2009.

34. Lúanaigh $\mathrm{PO}$, Hughes $\mathrm{F}$. The nurse executive role in quality and high performing health services. J Nur Manag [Internet]. 2016 Jan; [cited 2018 Jan 25];24(1):132-6. Available from: http://onlinelibrary.wiley.com/ doi/10.1111/jonm.12290/abstract;jsessionid=BAB6556E79D226155C 4D4FED0CC35B22.f01t01? systemMessage=Please+be+advised+tha $\mathrm{t}+$ we+experienced+an+unexpected+issue+that+occurred+on+Saturd ay+and+Sunday+January+20th+and+21st+that+caused+the+site+to +be+down+for+an+extended+period+of+time+and+affected+the+ab lity+of+users+to+access+content+on+Wiley+Online+Library.+This+is sue+has+now+been+fully+resolved.++We+apologize+for+any+incon venience+this+may+have+caused+and+are+working+to+ensure+tha $t+w e+c a n+a l e r t+y o u+i m m e d i a t e l y+o f+a n y+u n p l a n n e d+$ periods $+o f+d$ owntime+or+disruption+in+the+future

35. Hwang JI, Park HA. Relationships between evidence-based practice, quality improvement and clinical error experience of nurses in Korean hospitals. J Nurs Manag [Internet]. 2015 Jul; [cited 2018 Jan 25] 23(5):651-60. Available from: https://www.ncbi.nlm.nih.gov/pubmed/?t erm=Hwang+Jl\%2C+Park+HA.+Relationships+between+evidence-ba sed+practice\%2C+quality+improvement 